\title{
Relapses in Wegener's granulomatosis: the role of infection
}

\author{
A J PINCHING, A J REES, B A PUSSELL, C M LOCKWOOD, R S MITCHISON, D K PETERS
}

\section{Summary and conclusions}

Out of 20 relapses that occurred in patients with Wegener's granulomatosis, nine were provoked by bacterial or viral infection. Seven of these occurred during maintenance treatment in response to infection with common pathogens, and treatment of the infection alone was insufficient to produce remission. Circulating immune complexes were seen only in relapses due to infection and rarely in infections that occurred without relapse. A possible mechanism for infection-provoked relapses is that infection-derived complexes reactivate disease; alternatively, the acute-phase or cellular response to infection may enhance quiescent disease.

Infection may exacerbate Wegener's granulomatosis and other autoallergic diseases, but whether it does so by a common mechanism is not known and further study is required.

\section{Introduction}

A study of patients being treated for antiglomerular basementmembrane disease identified intercurrent infection as an important cause of relapse and led to the recognition of infectioninduced enhancement of antibody-mediated injury. ${ }^{1}$ Although its cause is still not clear, several mechanisms have been considered, including activation of inflammatory cells in response to infection, increased concentrations of acute-phase proteins such as fibrinogen and C-reactive protein, and the superimposition of infection-derived immune complexes. We report here on part of a prospective analysis of the effect of infection in autoallergic diseases, which investigated the importance of infection in relapses of Wegener's granulomatosis, a condition of uncertain aetiology but probably having an allergic pathogenesis of immune complex type. Enhanced tissue injury after infection has also been noted in other immunologically mediated diseases, ${ }^{2-8}$ and the possibility arises that exacerbation of allergic tissue damage by infection might be a more general phenomenon.

\section{Patients and methods}

We studied 18 patients with Wegener's granulomatosis. Three died early in the course of their disease, and the remainder were followed up for periods ranging from three months to three years; eight are still alive. Treatment was generally started with a regimen including cyclophosphamide, azathioprine, and prednisolone and in some cases plasma exchange (referred to later as the "induction

Department of Medicine, Royal Postgraduate Medical School, Hammersmith Hospital, London W12 0HS

A J PINCHING, DPHIL, MRCP, research fellow and honorary senior registrar A J REES, MSC, MRCP, consultant physician and honorary senior lecturer in nephrology

B A PUSSELL, MB, FRACP, research fellow

C M LOCKWOOD, MRCP, senior clinical research fellow

D K PETERS, FRCP, professor of medicine

Department of Bacteriology, Royal Postgraduate Medical School R S MITCHISON, MB, medical assistant phase"); patients were thereafter maintained with low-dose prednisolone and, after relapse, cyclophosphamide or azathioprine. Routine clinical, haematological, biochemical, bacteriological, virological, serological, and radiological tests were performed including regular microbiological sampling and assays for immune complex and C-reactive protein (at least three times a week during induction). In particular, a standard protocol of microbiological investigation of fever and other indicators of infection or of an unexplained increase in disease activity was used to identify possible infective organisms. This protocol included culture of blood, throat swabs, sputum, urine, surgical wounds, and other sites of infection; viruses were sought by direct sampling of lesions and urine cytology for viral inclusions as well as by viral serology; and bronchoscopic sampling and transbronchial biopsy were carried out to investigate unexplained parenchymal pulmonary shadowing. Circulating immune complexes were sought using a $\mathrm{Clq}$ binding assay. ${ }^{9}$

Infection was defined as a clinically identifiable episode in which the patient had symptoms or signs, or both, consistent with infection by the organism isolated or implicated and that could not be attributed to disease activity alone. Relapse was defined as evidence of recrudescence of or increase in the severity of symptoms or signs readily attributable to the underlying disease and not explicable in terms of infection alone. When relapse closely followed an acute reduction in drug treatment this was taken, for the purpose of the study, to be the precipitant. Relapses were crudely classified as "granulomatous"manifested by pulmonary nodules or interstitial shadowing-or "vasculitic"-manifested by pulmonary haemorrhage (increase in diffusion factor for carbon monoxide corrected for alveolar volume and haemoglobin ${ }^{10}$ ), nephritis, peripheral neuropathy, cerebral vasculitis, cutaneous vasculitis, episcleritis, and myopathy. For the purpose of analysing the association of relapse or infection, or both, with changes in circulating immune complexes and C-reactive protein we used only the results of the assays on a single serum sample, taken at the onset of the event. Statistical analysis was carried out using the $\%^{2}$ test with Yates's correction.

\section{Results}

Of the 15 patients followed up, nine relapsed. Tables I and II show the events associated with the 20 relapses in these patients.

TABLE I-Events associated with relapse

\begin{tabular}{ccccc}
\hline & & $\begin{array}{c}\text { No of } \\
\text { relapses }\end{array}$ & $\begin{array}{c}\text { No of } \\
\text { patients }\end{array}$ \\
\hline $\begin{array}{c}\text { Infection } \\
\text { Reduction in drugs }\end{array}$ & $\cdots$ & 9 & 5 \\
$\begin{array}{c}\text { prescribed } \\
\text { Unidentified }\end{array}$ & $\cdots$ & $\ldots$ & 7 & 4 \\
\hline Total & & & 20 & $9^{*}$ \\
\hline
\end{tabular}

*Relapses at various times in the same patien were sometimes associated with different events.

Infection was associated with almost half the relapses, and in no case did an infection-associated relapse occur soon after a reduction in treatment. Table III gives the details of the infections. Bacterial infections comprised staphylococcal shunt infection with septicaemia (one); Bacillus subtilis bacteraemia (one); infection of urinary tract with Klebsiella aerogenes (one); and respiratory tract infections (four), from two of which Haemophilus influenzae was isolated. The viral infections were respiratory and diagnosed serologically as being due to influenza B and respiratory syncytial virus. In this admittedly small series there was a trend for the site of infection to influence the site of relapse. All of the six respiratory infections associated with 
relapse provoked pulmonary relapse, in addition to recrudescence of distant vasculitis in four patients and nephritis in two; a urinary infection and septicaemia led to exacerbation of nephritis. Furthermore, bacterial infection seemed to be followed most often by vasculitic relapse, though the numbers are too small for statistical analysis.

TABLE II-Nature of relapse and associated events

\begin{tabular}{lccccc}
\hline & $\begin{array}{c}\text { No of } \\
\text { relapses }\end{array}$ & $\begin{array}{c}\text { No of } \\
\text { patients }\end{array}$ & Granulomatous* & Vasculitict \\
\hline Bacterial infection & 7 & 5 & 2 & 5 \\
Viral infection & 2 & 2 & 1 & 1 \\
$\begin{array}{l}\text { Cyclophosphamide dosage } \\
\text { reduced }\end{array}$ & 4 & 1 & 3 & 1 \\
$\begin{array}{l}\text { Steroid dosage reduced } \\
\text { Unidentified }\end{array}$ & 3 & 3 & & 4 \\
\hline
\end{tabular}

*Granulomatous relapse $=$ Pulmonary nodules, interstitial shadowing (no haem* Granulome.

†Vasculitic relapse $=$ Pulmonary haemorrhage, nephritis, peripheral neuropathy, cerebral vasculitis, cutaneous vasculitis, episcleritis, myopathy.

TABLE III-Details of infections

\begin{tabular}{|c|c|c|}
\hline Site & $\begin{array}{l}\text { Major symptoms and signs } \\
\text { referable to infection }\end{array}$ & Microbiology \\
\hline $\begin{array}{l}\text { Arteriovenous } \\
\text { shunt (blood) }\end{array}$ & $\begin{array}{l}\text { Fever. Purulent exudate from } \\
\text { shunt. Clinically septicaemic. } \\
\text { Response to phenoxy- } \\
\text { methylpenicillin and } \\
\text { flucloxacillin }\end{array}$ & $\begin{array}{l}\text { Staphylococcus aureus from } \\
\text { shunt swab (heavy growth) }\end{array}$ \\
\hline Blood & $\begin{array}{l}\text { Fucroxacimin Clinically septicaemic. } \\
\text { Response to phenoxy- }\end{array}$ & $\begin{array}{l}\text { Bacillus subtilis in five of six } \\
\text { blood-culture bottles }\end{array}$ \\
\hline Urine & $\begin{array}{l}\text { methylpenicilln } \\
\text { Fever. Dysuria. Frequency. } \\
\text { Response to gentamicin }\end{array}$ & $\begin{array}{l}\text { Midstream specimen of urine: } \\
\text { pyuria; Klebsiella aerogenes } \\
\text { (moderate growth) isolated }\end{array}$ \\
\hline Respiratory & $\begin{array}{l}\text { Fever. Dry cough. Pronounced } \\
\text { malaise }\end{array}$ & $\begin{array}{l}\text { Fivefold rise in titre to } \\
\text { respiratory syncytial virus } \\
\text { starting at time of clinical } \\
\text { infection }\end{array}$ \\
\hline Respiratory & Fever. Cough. Purulent sputum. & No sample before antibiotics \\
\hline Respiratory & $\begin{array}{l}\text { Fever. Purulent nasal discharge. } \\
\text { Maxillary sinus pain and } \\
\text { tenderness. Response to }\end{array}$ & $\begin{array}{l}\text { No bacterial or viral isolate; } \\
\text { presumed bacterial }\end{array}$ \\
\hline Respiratory & $\begin{array}{l}\text { Fever. Purulent sputum. } \\
\text { Response to co-trimoxazole }\end{array}$ & $\begin{array}{l}\text { Sputum yielded Haemophilus } \\
\text { influenzae }\end{array}$ \\
\hline Respiratory & $\begin{array}{l}\text { Fever. Dry cough. "Flu-like } \\
\text { illness" }\end{array}$ & $\begin{array}{l}\text { Fourfold rise in titre to } \\
\text { influenza B virus }\end{array}$ \\
\hline Respiratory & $\begin{array}{l}\text { Fever. Purulent sputum. } \\
\text { (Bronchiectasis). Response to } \\
\text { amoxycillin }\end{array}$ & $\begin{array}{l}\text { Sputum yielded Haemophilus } \\
\text { influenzae }\end{array}$ \\
\hline
\end{tabular}

During the induction of remission-that is, the first six to eight weeks of cyclophosphamide treatment and until steroids were reduced to baseline dosage-60 infections occurred, but only two of these caused recognisable exacerbation of disease activity; both were bacteraemias (two of the three identified). On the other hand, during maintenance treatment 15 infections were clinically apparent (many of them mild), of which seven were followed by relapse.

Circulating immune complexes, as detected by C1q binding, were found during five of the nine relapses associated with infection and none of the 10 relapses tested that were not associated with infection $\left(\chi^{2}=4.95, p<0.05\right)$. Only four of the 46 infections not associated with relapse were accompanied by circulating immune complexes $\left(\chi^{2}=\right.$ $8.90, p<0.01$ ); two of these four were immediately consecutive infections in one patient and the other two occurred in a patient so ill from pulmonary infection that relapse could not have been diagnosed. Concentrations of C-reactive protein were raised in seven out of eight relapses tested that were associated with infection and in two out of nine relapses not associated with infection $\left(\chi^{2}=4.86, p<0.05\right)$; raised concentrations were also found in 10 out of 44 other infections, not associated with relapse $\left(\chi^{2}=10 \cdot 13\right.$, $\mathrm{p}<0.01$ ).

In most instances relapse associated with infection was managed by treating both the infection and the relapse (by escalating treatment with steroids, cyclophosphamide, or azathioprine) concurrently. In two patients, however, treatment of the infection alone did not resolve the reactivated disease, which progressed until specific treatment was started.

Sudden reduction in or withdrawal of treatment led to relapse in several patients (table I). After attempts to reduce the cyclo- phosphamide dosage in one patient with "limited" (non-renal) Wegener's granulomatosis four relapses occurred, in three of which the patient showed pulmonary nodules and classical granulomas, while the fourth was a vasculitic relapse that occurred when the patient was not being maintained on steroids. Three patients relapsed when steroids were withdrawn; two had been in remission for over a year, while in the other the relapse (due to non-compliance) occurred four months after a previous one. All such relapses were vasculitic, two of the patients having mononeuritis and one myopathy.

Of the four relapses for which precipitating factors could not be identified, two were due to isolated cerebral events. Although cerebral vasculitis seemed the most likely explanation, other diagnoses were also possible: the first patient, a man of 67 , with previous cerebral disease affecting the same motor area, may have had a thrombotic occlusion superimposed on healed vasculitis; the other, a 66-year-old man with no previous cerebral disease, had atrial fibrillation and may have had a cerebral embolism. Thus only two relapses were definitely not attributable to infection or a reduction in treatment.

\section{Discussion}

We identified intercurrent infection as a precipitant of relapse in patients with Wegener's granulomatosis, a phenomenon reminiscent of the enhancement of injury by infection in antiglomerular basement-membrane disease. ${ }^{1}$ Whereas the primary immunopathogenesis of the latter disease is well defined and due to an autoantibody (type 2 reaction), the immunopathogenesis of Wegener's granulomatosis is less clear, although immune complexes (type 3 reaction) are implicated (A J Pinching et al, paper in preparation). ${ }^{11}$ Clinically, our findings show that early diagnosis and treatment of infection and awareness that relapse may be precipitated are important. Treatment of infection alone, however, was insufficient to lead to remission, and specific treatment for the underlying disease was also required.

Certain other aspects emerged from this study. The site of infection appeared to determine the sites of relapse, possibly by influencing the localisation of circulating immune complexes or inflammatory mediators. That only few relapses occurred in the induction period is interesting, for it is then that infections were most common; moreover, the patients were then subject to careful monitoring in hospital, which should, if anything, have permitted more ready recognition of increased disease activity. Possibly the more intensive immunosuppressive treatment used in induction prevents expression of the immunopathogenetic processes activated by infection. Relapse that occurred after a change in treatment during maintenance was also important, and it was notable that relapses occurring after a reduction in steroids were always vasculitic, while those occurring after a reduction in cyclophosphamide were generally granulomatous; this may point to different and complementary roles for these two drugs in controlling the disease.

Circulating immune complexes are commonly found during the initial period of active Wegener's granulomatosis (A J Pinching et al) ${ }^{11}$; this, however, does not explain the localisation in particular tissues and distinctive features of this form of disseminated vasculitis. Interestingly, recurrence of circulating immune complexes was exclusively associated with infectionprovoked relapse and intercurrent infections not causing relapse rarely caused detectable circulating immune complexes. The type of infection associated with relapse (apart from the earlyoccurring bacteraemias) did not seem to be unusual. This raises two possibilities: either the nature of the infections causing relapse leads to the reappearance of circulating immune complexes or the complexes especially reflect reactivation of disease by infection. The association of complexes and initial disease activity makes it probable that the presence of complexes in infection-provoked relapses reflects reactivated disease, perhaps with the provision of an increased load of complexes by the infection.

The idea that the presence of complexes in the circulation may be due to defective clearance by the reticuloendothelial system is gaining ground, particularly after studies of splenic 
function in putative immune complex disease. ${ }^{12} 13$ Some of our patients were found by Lockwood et $a l^{12}$ to have defective splenic function during their initial disease, which was reversed by a plasma exchange regimen. The effect of infection on splenic reticuloendothelial function and its relation to the reappearance of circulating immune complexes in infectionprovoked relapse clearly warrant further study. A role for infection in the pathogenesis of Wegener's granulomatosis is further suggested by the observation that 10 of the 18 patients studied had a history of chronic suppurative infection of the respiratory tract, which long predated the vasculitic illness (A J Pinching et al); four of the five patients with infectionprovoked relapse had such a history.

Another possible mechanism for infection-provoked relapse is the enhancement of quiescent disease by the acute-phase or cellular response to infection: a limited amount of immunopathogenetic initiator (for example, circulating immune complex) may cause more tissue injury as a result of the provision of an increased supply of inflammatory mediators.

The phenomenon of infection-provoked enhancement of allergic tissue injury is seen in conditions of widely differing pathogenesis including autoantibody-mediated diseases such as antiglomerular basement-membrane disease ${ }^{1}$ and myasthenia gravis, immune complex disease such as systemic lupus erythematosus, $^{2}$ renal graft rejection, ${ }^{3}$ and in this study Wegener's granulomatosis. Infection may also exacerbate disease in asthma and infantile eczema. Whether infection exacerbates these varying allergic diseases by a common mechanism is not known. Clearly further studies of this clinically and theoretically important phenomenon are required.

We are grateful to the clinical virology department for carrying out the virological procedures.

\section{References}

1 Rees AJ, Lockwood CM, Peters DK. Enhanced allergic tissue injury in Goodpasture's syndrome by intercurrent bacterial infection. $\mathrm{Br} \mathrm{MedF}$ $1977 ; \mathrm{ii}: 723-6$.

2 Dubois EL. Lupus erythematosus. 2nd ed. Los Angeles: University of South California Press, 1974.

${ }^{3}$ Simmons RL, Weil R, Tallent MB, Kjellstrand CM, Najarian JS. Do mild infections trigger the rejection of renal allografts ? Transplant Proc $1970 ; 2: 419-23$.

4 David DS, Millian SJ, Whitsell JC, et al. Viral syndromes and renal homograft rejection. Ann Surg 1972;175:257-9.

5 Briggs JD, Timbury MC, Paton AM, Bell PRF. Viral infections and renal transplant rejection. $B r$ Med $\mathcal{F} 1972$;iv:520-2.

${ }^{6}$ Lopes C, Simmons RL, Mauer M, Park B, Najarian JS, Good RA. Role of virus infections in immunosuppressed renal transplant patients. Transplant Proc 1973;5:803-8.

7 Dossetor JB, Schlant J, Olson LA, Zabriskie JB. Streptococcal infection as a cause of hyperacute renal allograft rejection. Transplant Proc 1978; 10:483-7.

${ }^{8}$ Byrd LH, Tapin L, Cheigh JS, Aronian J, Stenzel KH, Rubin AL. Association between Streptococcus faecalis urinary infections and graft rejection in kidney transplantation. Lancet 1978;ii:1167-9.

9 Pussell BA, Lockwood CM, Scott DM, Pinching AJ, Peters DK. Value of immune complex assays in diagnosis and management. Lancet 1978;ii:359-63.

10 Ewan PW, Jones HA, Rhodes CG, Hughes JMB. Detection of intrapulmonary haemorrhage by carbon monoxide uptake: a new method and its application in Goodpasture's syndrome. N Engl f Med 1976;295: 1391-6.

11 Fauci AS, Haynes BK, Katz P. The spectrum of vasculitis. Ann Int Med $1978 ; 89: 660-76$.

12 Lockwood CM, Worrledge S, Nicholas A, Cotton C, Peters DK. Reversal of impaired splenic function in patients with nephritis or vasculitis (or both) by plasma exchange. $N$ Engl f Med 1979;300:524-30.

${ }^{13}$ Frank MM, Hamburger MI, Lawley TJ, Kimberly RD, Plotz PH. Defective reticulo-endothelial system Fc-receptor function in systemic lupus erythematosus. $N$ Engl $\mathcal{F}$ Med 1979;300:518-23.

(Accepted 8 August 1980)

\section{SHORT REPORTS}

\section{Recurrent abdominal pain associated with digoxin in a patient undergoing maintenance haemodialysis}

In addition to its inotropic effect on the heart digitalis is a direct peripheral vasoconstrictor. ${ }^{1}$ In particular, cardiac glycosides cause splanchnic vasoconstriction and reduced mesenteric blood flow in dogs, ${ }^{2}$ monkeys, ${ }^{3}$ and variably in patients with congestive heart failure. ${ }^{4}$ There is a well-recognised association of administration of digitalis with intestinal infarction, ${ }^{5}$ but digitalis has not been associated before with chronic intestinal ischaemia or abdominal angina.

\section{Case report}

A 55-year-old obese white man was admitted to hospital because of abdominal pain. He had been maintained on thrice weekly haemodialysis for two and a half years because of renal failure caused by nephrosclerosis. $\mathrm{He}$ had a history of duodenal ulcer, hiatus hernia, myocardial infarction, and angina pectoris. His medications included digoxin $0.25 \mathrm{mg}$ every other day and nitroglycerin $0.4 \mathrm{mg}$ sublingually as needed.

Soon after starting haemodialysis he began to have severe recurrent, sustained, central, non-radiating abdominal pain brought on by physical exertion and relieved after 10-20 minutes by lying supine. The pain often occurred after dialysis, especially when he had required fluid removal in excess of two litres and had become hypotensive. The pain was never related to meals; and he had had no weight loss, diarrhoea, melaena, or rectal bleeding. Radiographs of the upper gastrointestinal tract and gall bladder were normal.

$\mathrm{He}$ was pale, sweating, and in great distress. The blood pressure was $100 / 60 \mathrm{~mm} \mathrm{Hg}$, and results of cardiac and respiratory examinations were normal. There was mild tenderness in the hypogastrium with no rebound tenderness, and the bowel sounds were active. Results of Hemoccult test of the stool were negative. His haemoglobin concentration was $13.3 \mathrm{~g} / \mathrm{dl}$ packed cell volume $0.4(40 \%)$, and peripheral blood leucocyte count $6 \cdot 1 \times$ $10^{2} / 1\left(6100 / \mathrm{mm}^{3}\right)$. There was no biochemical or electrocardiographic evidence of new myocardial injury. A plain film of the abdomen showed a non-specific gas pattern and heavily calcified abdominal aorta and iliac vessels.

We suspected that the pain was due to mesenteric vascular disease, and abdominal angiography was planned after a trial of withholding treatment with digoxin. This lasted for the next five months, and though the dialysis regimen was unaltered the patient had no further abdominal pain. To test whether digoxin was the provocative agent the patient was rechallenged with digoxin, and recurrence of abdominal pain after dialysis was noted after $1.0 \mathrm{mg}$. Digoxin was again withdrawn, and he has since remained free of pain.

\section{Comment}

Intestinal angina is a syndrome of postprandial abdominal pain and weight loss associated with minimal physical findings. We believe that this case represents a variation of this syndrome and that the abdominal pain was a result of intestinal ischaemia, since it was induced by factors that either reduce cardiac output or cause splanchnic vasoconstriction-namely, contraction of the intravascular volume by rapid fluid removal during ultrafiltration-haemodialysis and physical exertion. Since digitalis acts as a direct splanchnic vasoconstrictor, ${ }^{23}$ relief of this patient's pain after discontinuing digoxin and the recurrence when rechallenged support the belief that the pain represented intestinal ischaemia that was exacerbated by digoxin.

A syndrome of digoxin-induced abdominal pain has not been reported in patients undergoing dialysis, many of whom take digitalis, have calcified aortas, and often undergo the stress of rapid fluid removal. To explain why this patient experienced pain and apparently similar patients do not is difficult. An additional predisposing factor for this patient was his packed cell volume, which was unusually high 